\title{
Swimming in Limeira city: infrastructure, public policies and pedagogical perspectives.
}

\author{
Bruna L. Bueno*, Alcides J. Scaglia, Leandro C. Mazzei, Thomaz C. de Almeida.
}

\begin{abstract}
Good sports policies should minimally take into account facilities for the sport practice, support of sport organizations and pedagogical programs in keeping with the target audience. This study aimed to analyze the development of swimming in a city in the State of São Paulo, considering the sport policies, sport facilities and pedagogical programs for the practice of this sport. The methodology made use of documentary research, geospatial analysis and semi-structured interviews. The results point mainly to the need to know the profile and expectations of the public to propose policies that are more appropriate and effective.
\end{abstract}

Key words: Sports policies, sports management, swimming.

\section{Introduction}

In order for good and effective policies related to sport practices, they must take into account: (1) Sport structures and facilities to develop sport practice programs; (2) support from sport organizations, such as federations, clubs and associations for effective occupation of facilities, and (3) pedagogically wellplanned and executable programs, consistent with the reality and expectation of the target audience 1 . Therefore, this research project aims to present the conditions that involve the development of swimming in a Municipal Sports Policy (city of Limiera), considering its facilities, pedagogical projects and possible sport organizations involved.

\section{Results and Discussion}

First, a documental research was made of public documents referring to facilities, swimming pool, sport projects and policies that allow the development of swimming in Limeira. With these data, the mapping of the pools was carried out and through the software ArcMap from ESRI's ArcGIS suite of geospatial processing programs, an instrument of Geographic Information System, datas about the population, education, health and social vulnerability regarding the envirornment of each facility were obtained. It was also delimited an area of comprehension with radius of 1 kilometer from each pool. After this step, the participants (5 coaches and 6 practitioners) of one of the projects were selected for a semi-structured interview in order to obtain information about their expectations regarding the projects and what it offers and enables. These interviews were submitted to the Content Analysis method ${ }^{2}$. The obtained results show there are 9 public and municipal management $(A, B, C$, $D, E, F, G, H$ and I). Among these 9 public, in 3 is not provided swimming sport projects (Figure 1). The populational and socioeconomical results obtained from the GIS method are presented in Table 1. And after the interviews, by the Content Analysis the following categories were determined: Infrastructure, Public Policies, Pedagogical Management and Perspective of future. From the interview, a Pedagogical Management emerged, as a model of methodology and didactics that guarantees the continuity in the sport development, from the initiation to the performance.
Figure 1. Location of swimming pools in the city of Limeira-SP

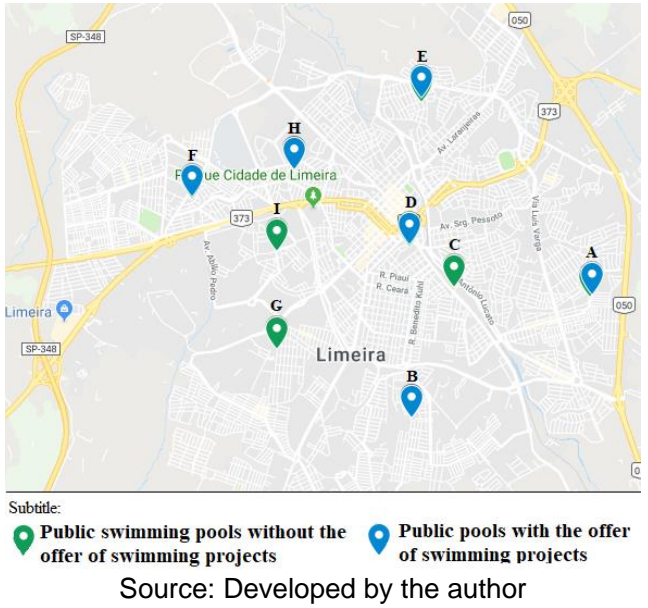

Table 1. Results of the analysis factors of each pool

\begin{tabular}{|c|c|c|c|c|c|c|c|c|c|c|}
\hline \multirow[t]{2}{*}{ Categories } & \multirow[t]{2}{*}{ Factors of Analysis } & \multicolumn{9}{|c|}{ Swimming Pools } \\
\hline & & A & B & C & D & E & $\mathbf{F}$ & G & H & I \\
\hline \multirow[t]{2}{*}{ Population } & Number of inhabitants & 23309 & 20832 & 15136 & 13956 & 12966 & 12614 & 11475 & 9433 & 8876 \\
\hline & $\begin{array}{l}\text { Number of } \\
\text { neighborhoods covered }\end{array}$ & 25 & 31 & 51 & 33 & 29 & 33 & 29 & 33 & 38 \\
\hline \multirow[t]{2}{*}{ Education } & $\begin{array}{l}\text { Number of public } \\
\text { schools }\end{array}$ & 10 & 9 & 7 & 12 & 5 & 7 & 3 & 6 & 4 \\
\hline & $\begin{array}{l}\text { Number of private } \\
\text { schools }\end{array}$ & 0 & 1 & 11 & 25 & 2 & 5 & 1 & 7 & 1 \\
\hline Health & $\begin{array}{l}\text { Number of health } \\
\text { organs }\end{array}$ & 4 & 2 & 11 & 10 & 2 & 3 & 1 & 2 & 3 \\
\hline \multirow[t]{2}{*}{$\begin{array}{l}\text { Social } \\
\text { Vulnerability }\end{array}$} & $\begin{array}{l}\text { Proportion of children } \\
\text { aged } 0 \text { to } 5 \text { years in the } \\
\text { population }\end{array}$ & 8,01 & 7,84 & 5 & 4,22 & 6,05 & 6,51 & 7,08 & 4,55 & 5,29 \\
\hline & $\begin{array}{l}\text { Average wage income } \\
\text { per capita }(\mathrm{R} \$)\end{array}$ & 558,6 & 573,6 & 928,2 & 1291 & 756,9 & 683,3 & 689,3 & 1053 & 993,3 \\
\hline
\end{tabular}

From the results it can be observed that the city has a great potential for the development of swimming, with a large number of swimming pools, with good policies that foment the sport and a pedagogical management of the sport. The results of the GIS method also point out a good tool to the development of sport policies.

\section{Conclusions}

It is concluded that a public sports policy involves a good management of the sport. And to do this, understanding the profile of the target audience, as well as their expectations, is extremely necessary for such policies to be consistent, efficient and effective.

${ }^{1}$ CARVALHO, M. J. O desporto como matéria de interesse público: da lei à realidade. XV Congresso de Ciência do Desporto e Educação Física dos Países de Língua Portuguesa. Mesa Temática de Lazer: políticas públicas e sociedade. Anais...Recife: 2014

2 BARDIN, L. Análise de conteúdo. Lisboa: Edições 70, 2009 